Вісник Національного університету “Львівська політехніка”. Серія "Проблеми економіки та управління"

№ 2(8), 2020

\title{
ПРОБЛЕМИ УПРАВЛІННЯ
}

УДК: 334.752:334.012.23

JEL Classification Code $\mathbf{H 4 3}$

О. І. Білик, Ю. О. Блинда, Н. М. Крохмальна

Національний університет “Львівська політехніка", кафедра адміністративного та фінансового менеджменту

\section{ОСОБЛИВОСТІ УПРАВЛІННЯ СОЦІАЛЬНИМИ РИЗИКАМИ В УМОВАХ РОЗВИТКУ ДОРОЖНЬОЇ КОНЦЕСІЇ}

http://doi.org/10.23939/semi2020.02.115

() Білик О. І., Блинда Ю. О., Крохмальна Н. М., 2020

Визначаючи системність розвитку держави, науки, економіки і суспільства через призму пошуку альтернативних джерел інвестування у дорожню галузь, в статті автори обгрунтували соціальні ризики, які виникають у разі застосування сублімативної форми фінансування розвитку дорожньої галузі через запровадження принципів державноприватного партнерства. Інвестування бізнесом у дорожню галузь в Україні у сучасних умовах ризикове через недосконалість законодавства, низький розвиток технологій, що можливо подолати, запроваджуючи концесійні підходи до розвитку галузі. Досліджено також вплив державно-приватного партнерства на соціальні ризики і запропоновано напрями їх мінімізації.

Ключові слова: державно-приватне партнерство; дорожня галузь; соціальні ризики; дорожня інфраструктура.

Постановка проблеми

Протягом останніх десятиліть основні державні органи провідних країн світу, що здійснюють управління дорожньою галуззю, демонстрували дедалі сильнішу тенденцію до пошуку альтернативних шляхів створення та впровадження концесійних систем дорожньої інфраструктури 3 метою зробити це надійним, соціально-економічно стійким та економічно ефективним способом.

Це явище зумовлено передусім зростанням ризиків, пов'язаних із формуванням системи концесій дорожнього руху, та ризиком, спричиненим запровадженням вимог щодо оплати дорожнього збору. Попри позитивний як соціальний, так і економічний ефект, в Україні дорожньоприватне партнерство (ДПП) може зіткнутися також зі зростанням соціального ризику, зокрема через те, що учасники дорожнього руху сприймають дорожній збір як додатковий податок. Саме соціальний ризик у розвинених країнах світу протягом останніх років стає дедалі важливішим фактором, який необхідно враховувати, запроваджуючи платні проєкти в умовах дорожньої концесії.

\section{Аналіз останніх досліджень і публікацій}

Плата за дороги - не нова концепція у світі. Записи свідчать про те, що мито збирали в VII ст. до н. е. Протягом століть у всьому світі все ширше впроваджувалася практика принципу оплати, стягнення із користувача плати за користування дорогою. У сучасних умовах дослідженням дорожньої концесії займалися такі вчені, як І. Бернштейн [1], О. Вікарчук [2], Н. Кирилова [3] Ю. Маковська [4] М. Арата [5], О. Солодовнік [6], Т. Печончик [7] тощо. Обгрунтування суті та рекомендацій щодо управління соціальними ризиками здійснили у своїх працях О. Білик [7], 
Дж. Ван Вик [9] та ін., проте не обгрунтувано напрями управління соціальними ризиками в умовах дорожньої концесії.

\section{Постановка цілей}

Зважаючи на проблематику дослідження, цілі статті такі:

- визначення та аналіз стану державно-приватного партнерства в Україні;

- виокремлення причин та наслідків розвитку соціальних ризиків в умовах дорожньої концесії на основі аналізування міжнародного досвіду щодо застосування плати за проїзд по автомагістралях;

- обгрунтування основних напрямів управління соціальними ризиками в умовах дорожньої концесії та формування відповідних висновків.

\section{Виклад основного матеріалу}

Законодавчу сферу побудови правових взаємовідносин у сфері державно-приватного партнерства сьогодні визначено у Законі України “Про концесію”, який набув чинності 3 жовтня 2019 року. Зазначений закон розширює можливості у сфері застосування концесії [10].

Під дорожньою концесією розуміємо передавання уповноваженим органом виконавчої влади чи органом місцевого самоврядування 3 метою забезпечення громадських потреб та розвитку дорожньої інфраструктури на підставі концесійного договору, платності та строковості юридичній чи фізичній особі права на будівництво, експлуатацію, ремонт магістралей національного та міжнародного значення (об’єкта концесії) із подальшим правом взяття плати за користування об'єктом концесії $[5,6,10]$.

Проте $\epsilon$ певні законодавчі упущення, які необхідно узгодити із екологічним законодавством. Потрібно врахувати, що основна роль належить власне партнерству, тобто рівновага розподілу ризиків та відповідальності між державним та приватним партнерами $є$ запорукою успішності концесійних проєктів. Приклад незбалансованості умов дорожньої концесії - запровадження проєкту дочірньою компанією італійського Агентства автомобільних доріг ANAS SpAв, призначення якого оцінювання доцільності та всебічної структуризації концесій на шляху через реалізацію ініціативи державно-приватного партнерства (ДПП) значної частини дорожньої мережі Республіки Колумбія. ANAS уклало два контракти на всебічне структурування близько 3000 км доріг, розділених на дев' ять лотів, четвертого покоління концесій, так звану програму 4G шосе. Перше, друге і третє покоління зазнали невдач саме через відсутність рівноваги. Насправді в першому поколінні всі ризики покладались на громадськість, що виявилось набагато дорожчим для уряду. У другому поколінні ситуація змінилася, унаслідок чого приватні особи або зазнали невдачі, або не виконали контракти. У третьому виявлено кращу рівновагу, але все ще відсутність чітких правил, що призвело до затримок, низького рівня послуг та рекламацій [5].

Під час укладання концесійних договорів необхідно враховувати наявність ризиків, оскільки уряди, спонсори та оператори в різних місцях світу стикаються із такими соціальними ризиками, як опір давальницьким та концесійним контрактам. Політичні опозиції наголошують на платному транспорті як додатковому чиннику негативного впливу платних доріг, а це все частіше призводить до незбалансованості та негативного сприйняття і розголосу [9]. Звичайно, така ситуація зменшує інвестиційну привабливість запропонованого концесійного контракту для приватного партнера. Річ у тім, що зацікавлені сторони все частіше очікують всеохопного та прозорого процесу участі на концептуальних етапах таких проєктів. У цьому сенсі необхідно визначити зацікавлені сторони як урядові відомства на всіх рівнях та в усіх відповідних підрозділах, учасників дорожнього руху, постраждалі громади та приватних осіб, працівників, політиків, підрядників, постачальників, засоби масової інформації тощо.

Органи виконавчої влади в інших країнах світу під час розгляду концесійних проєктів стикаються із труднощами, зокрема з тим, що політичні та соціальні процеси часто розглядають як просту формальність. Ризиком є саме неінформативність таких контрактів. Важливим кроком у системі мінімізації соціальних ризиків $€$ інклюзія та достовірна участь у концесії громадськості та громад. 


\section{Особливості управління соціальними ризиками в умовах розвитку дорожньої концесії}

Ще одним соціальним ризиком є також політичні втручання, які ускладнюють упровадження дорожньої концесії, щоб поставити умови щодо створення дорожньої інфраструктури.

Зазначимо, що в структурі вітчизняних договорів ДПП немає договорів саме дорожньої концесії, тобто ще не практикувались будівництво та експлуатація доріг на платній основі (рис. 1).

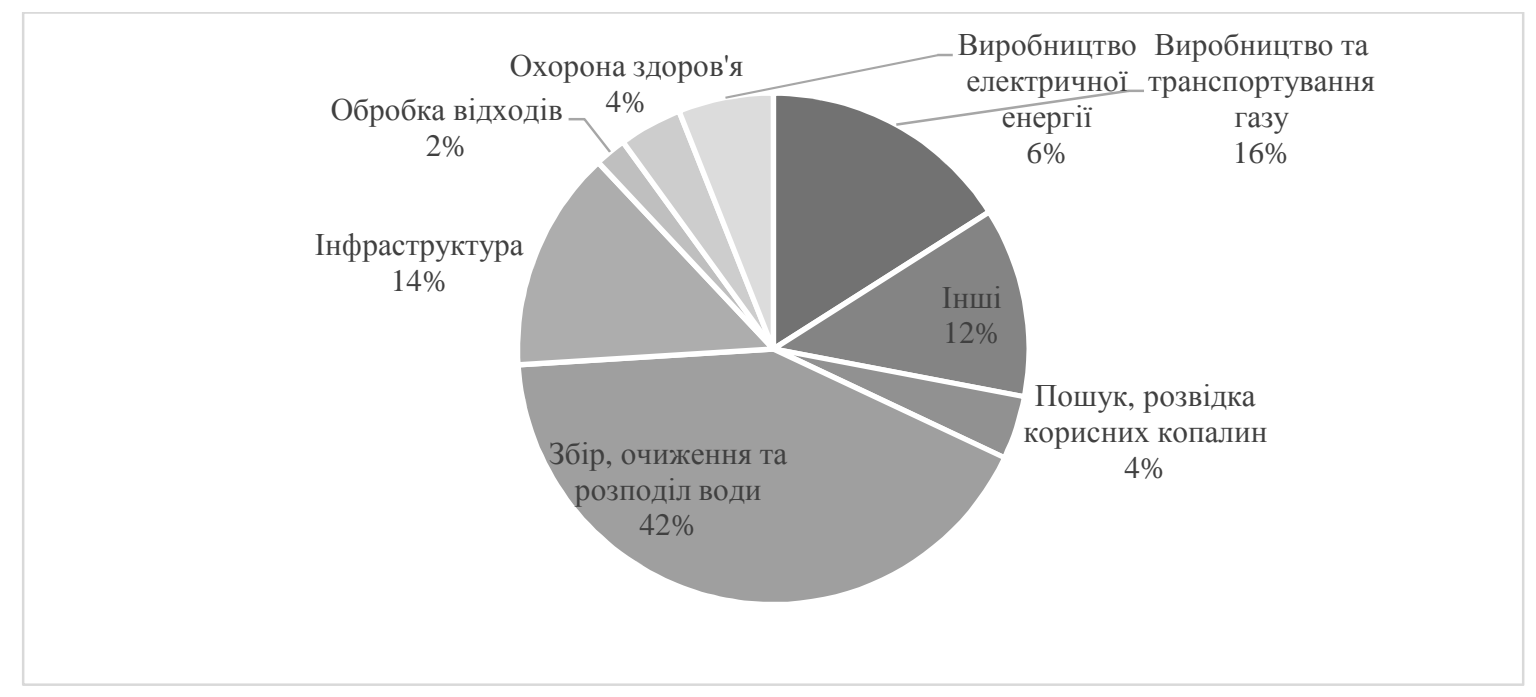

Рис. 1. Структура концесійних договорів в Украӥні*

* Склали автори на основі [11].

Дороги є невід'ємною частиною транспортної системи. Дорожня мережа країни повинна бути ефективною, щоб максимізувати економічні та соціальні вигоди. Вони відіграють істотну роль у досягненні національного розвитку та сприяють загальній роботі й соціальному функціонуванню громади. Відомо, що дороги підвищують мобільність, виводячи людей із ізоляції, а отже, і з бідності. Дороги відіграють дуже важливу роль у соціально-економічному розвитку країни, але тим часом це розширення також створює істотні виклики безпеці громадськості, яка подорожує. Промисловість автомобільного транспорту є основою сильної економіки та динамічного суспільства.

Отже, законним і необхідним є захист галузі, життєво важливої для економічного зростання, соціального розвитку, процвітання i, врешті-решт, миру, яка відіграє вирішальну роль у житті кожного в індустріальних країнах та країнах, що розвиваються, задовольняючи вимоги до стійкої мобільності як людей, так і товарів, що стало основною метою Великого будівництва в Україні й новою дорожньою стратегією. Проте, щоб поліпшити фінансування вітчизняної дорожньої галузі, потрібно скористатись досвідом розвинених країн, які запровадили і розвивають дорожні концесії.

Як вже зазначено вище, поряд із проєктними ризиками слід враховувати і наявність соціальних ризиків.

Соціальний ризик трактують як ймовірність настання несприятливих подій, спричинених втратою здоров'я, доходу, стихійного лиха, військових чи політичних дій, впливом на навколишнє середовище, унаслідок яких індивідуум чи група індивідуумів втрачають матеріальні блага та цінності, а також змінюють набуті соціальні комунікації та соціальне становище [8, с. 24].

Виокремимо основні причини виникнення соціальних ризиків. Проте спочатку необхідно виділити основні групи ризиків (рис. 2).

3 метою формування балансу економічних, екологічних та соціальних наслідків необхідно забезпечити належне встановлення чотирьох опор, необхідних для досягнення стійкого транспортного потоку:

- ефективне управління використанням землі та транспортуванням;

- справедливе, ефективне, стабільне фінансування;

- стратегічні інвестиції в інфраструктуру;

- увага до дизайну району. 


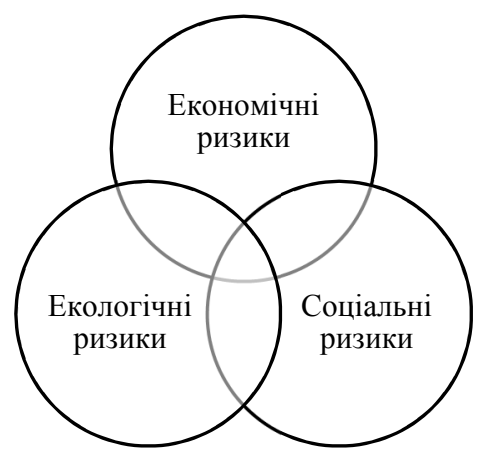

Рис. 2. Групи ризиків, які необхідно враховувати

у разі застосування дорожньої концесії*

* Згрупували автори.

Проте слід наголосити і на соціальній складовій, забезпечуючи екологічну стійкість, щоб запобігти непотрібному споживанню природних ресурсів (особливо невідновлюваних) та знизити велике споживання енергії, утворення твердих побутових відходів, глобальні викиди парникових газів, забруднення зовнішнього повітря та води, шкоду навколишньому середовищу, виснаження ресурсів тощо. Однак соціальний вимір сталого розвитку загальновизнаний, що означає відсутність чіткого визначення чи згоди. Зазвичай вузько визначена соціальна стійкість звертає увагу на соціальну рівність, свободу, придатність для життя громади, безпеку, здоров'я людей, цінності, переконання, гідність, уявлення про суспільство тощо. Проте в кожній групі зазначених ризиків основою $є$ конкретна людина відповідно 3 виокремленими соціальними ризиками. 3 цією метою автори розробили анкету, в якій жителям Зимновідської об'єднаної територіальної громади пропонували проранжувати елементи, які забезпечуватимуть соціальну стійкість (табл. 1), згрупувавши соціальні ризики (табл. 2) унаслідок побудови платної магістралі. Відповідно, пояснюючи елементи соціальної стійкості, автори зарахували конкретний елемент до відповідних рівнів (проєктний, системний, а також можливості вартісного вимірювання).

Таблиия 1

Елементи соціальної стійкості під час упровадження дорожньої концесії*

\begin{tabular}{|c|c|c|c|c|}
\hline $\begin{array}{c}\text { Умовні } \\
\text { позначення }\end{array}$ & Перелік елементів & Проєктний рівень & Системний рівень & $\begin{array}{c}\text { Вартісне } \\
\text { вимірювання } \\
\text { (співвідношення } \\
\text { ціни та якості) }\end{array}$ \\
\hline $\mathrm{C} 1$ & Рівний розподіл можливостей & + & + & + \\
\hline $\mathrm{C} 2$ & Освіта та навчання & & + & \\
\hline C3 & Структура управління & + & + & + \\
\hline $\mathrm{C} 4$ & $\begin{array}{c}\text { Здоров'я та забезпечення його } \\
\text { збереження }\end{array}$ & + & + & \\
\hline $\mathrm{C} 5$ & Працевлаштування & + & + & + \\
\hline C6 & Безпека & + & + & + \\
\hline $\mathrm{C} 7$ & Права людини & + & + & \\
\hline $\mathrm{C} 8$ & Права громади & + & + & + \\
\hline C9 & Наявність робочої сили & + & + & \\
\hline $\mathrm{C} 10$ & $\begin{array}{c}\text { Сумлінність виконання } \\
\text { поставлених завдань }\end{array}$ & + & + & \\
\hline $\mathrm{C} 11$ & Культурна спадщина & + & + & \\
\hline $\mathrm{C} 12$ & Залучення та розвиток громади & + & + & + \\
\hline $\mathrm{C} 13$ & Розвиток технологій & & + & + \\
\hline
\end{tabular}

* Розробили і дослідили автори. 


\section{Особливості управління соціальними ризиками в умовах розвитку дорожньої концесії}

Як уже згадувалося вище, передумовою мінімізації соціальних ризиків транспортних проєктів ДПП є реалізація соціальної стійкості. Традиційно соціальну стійкість можна розглядати як ступінь задоволення, оснований на перспективі соціальної справедливості, людської гідності та участі 3 соціологічного погляду [8, с. 156]. 3 урахуванням цього у табл. 1 виділено проєктний та системний рівні соціальної стійкості. Рівень проєкту підкреслює вплив проєкту на інтереси людей та соціальну стабільність, і ці елементи тісно пов'язані із громадянами, які проживають у районі проєкту, та діяльністю організацій, пов'язаних із концесійним проєктом. Системний рівень підкреслює вплив транспортної системи або міської системи на суспільство та громадянина зокрема, що впливає на ширший спектр, а елементи цього рівня зосереджуються на сучасних і майбутніх цінностях та зовнішніх ефектах (як позитивних, так і негативних) системи.

Отже, ці впливи можуть впливати на соціальну стійкість із різних аспектів. Крім того, для транспортного проєкту ДПП кінцевою метою $є$ досягнення співвідношення ціни та якості для державної послуги і товару. Визначення співвідношення ціни та якості є максимально досяжним результатом розвитку транспортного проєкту ДПП

Таблиия 2

Групування соціальних ризиків у разі дорожньої концесії*

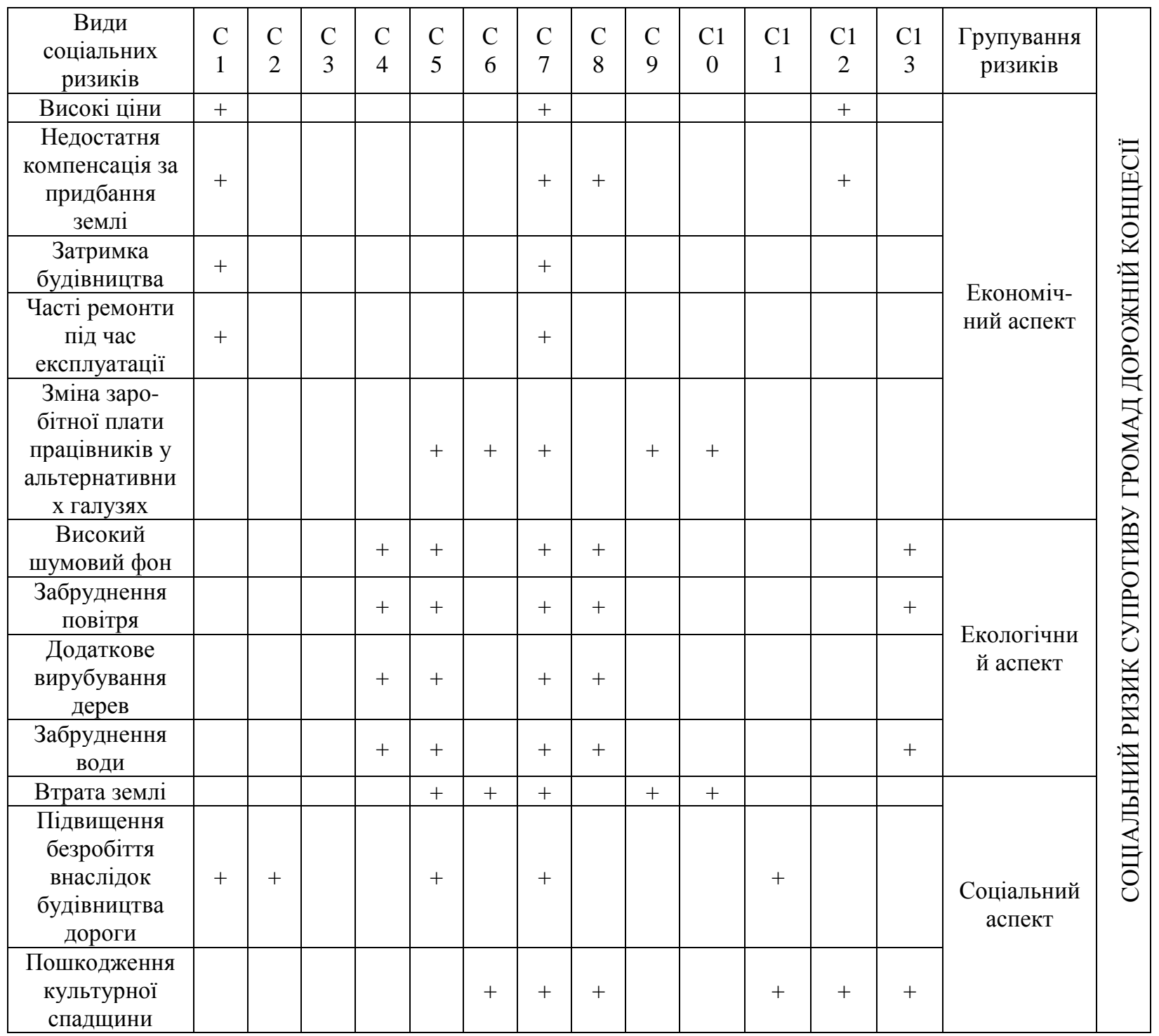

* Розробили і дослідили автори. 
Групування соціальних ризиків у вимірах трьох аспектів дає підстави для висновку про необхідність роботи із соціальними групами, тобто громадськістю.

Отже, для побудови якісних концесійних умов необхідно враховувати і участь громадськості. Участь громадськості пов'язана із обміном інформацією, ураховуючи всі переваги, зобов'язання та занепокоєння усіх зацікавлених сторін проєкту, щоб дати їм можливість безпосередньо впливати на прийняття рішень та результати такого проєкту. Інформація, яку обговорюють зацікавлені сторони, повинна охоплювати передбачувану інфраструктуру, оцінки впливу, положення пунктів збирання плати, процеси прийняття рішень та затвердження, фінансування, альтернативні маршрути, конструкції, тарифи та доступність, знижки та пільги, переваги, експлуатацію (дороги та аварії) управління), запобігання корупції та шахрайству, перевірку платіжних операцій тощо. Список великий і унікальний для кожного проєкту та кожної демографічної групи, і з ним потрібно боротися прозоро та ретельно.

Завдання участі громадськості у проєкті повинні бути такими:

- Створити форум участі, визначити зацікавлені та постраждалі сторони та узгодити засіб ефективного спілкування між учасниками.

- Заохочувати тих осіб чи організації, які мають право на консультацію, адекватною та надійною можливістю, щоб їх відверто вислухали на етапі формування проєкту.

- Забезпечити стійкий та постійний розвиток за допомогою інтерактивного планування та прогнозування.

- Сприяти розширенню знань, підвищенню обізнаності та розуміння громадськості. сторін.

- Управляти ризиками, внутрішньою політикою та суперечливими інтересами зацікавлених

- Здійснювати маркетинг проєкту.

Ці цілі неможливо досягти, якщо процес не впроваджується та не керується принципами активних, достовірних та всеохопних консультацій, доступу до осіб, які приймають рішення, та інформації, спільної відповідальності, уважності щодо викладених даних, цілісності, прозорості та чесності, а також ефективного спілкування. Громадськість повинна чітко розуміти, на які рішення та процеси можна або не можна впливати чи змінювати їх.

Посилаючись на принцип інклюзивності, важливо відзначити запропоновані процеси участі громадськості.

Процес слід розпочати із міжвідомчих засідань урядових органів, ураховуючи, що різні рівні та підрозділи урядових відомств не долучають громадськість та не інформують на підготовчих етапах, що спричиняє затримки та внутрішню бюрократію під час упровадження. Оцінювання впливу на навколишнє середовище та соціальну діяльність повинно значною мірою сприяти плануванню цього процесу. Одночасно із інклюзивним процесом участі в уряді розробники повинні шукати та виявляти всі зацікавлені сторони, на які впливатиме упровадження дорожньої концесії, причетні та зацікавлені сторін, формуючи своє управління, динаміку внутрішньої спільноти, групування, політику, структури та питання, що мають важливе значення, перед тим як залучати до участі громадськість. Отримавши таку інформацію, розробник зможе запросити до участі через засоби масової інформації, публічні зустрічі, бізнес-сектор, фокус-групи та представницькі групи, тобто церкви, школи, асоціації тощо. Отже, коли розробник звертається до зацікавлених сторін, вони повинні бути ретельно підготованими та інформованими.

Час розгляду різних аспектів та деталей участі також важливий. Наприклад, оголошення запланованих тарифів на плату за дорожній збір неминуче є одним із суперечливих питань щодо проєктів платних доріг. Громадськість повністю усвідомлює природу підготовчого фінансового моделювання в цьому плані та те, що тарифи (або дуже детальні проєктні оцінки) враховуються на ранній стадії проєкту і є початком бізнес-планування проєкту. Дотримання запланованих тарифів на плату повинно бути прозорим та доступним для розуміння зацікавлених сторін.

Небезпечно починати процес участі занадто пізно після прийняття рішень, оскільки терміновість і поспіх із встановленням термінів створює додаткові підозри, що спричиняють 
опір процесу. Зацікавлені сторони повинні знати, що можливість впливати на рішення та результати все ще реально існує.

Платформами участі необхідно керувати. Великі публічні зустрічі не дають змоги забезпечити зазначеної вище взаємодії. Якщо їх добре не підготовлено та ефективно не проведено під належним головуванням, часто зацікавлені сторони без значущої та конструктивної взаємодії з розробниками, урядами та виконавчими органами можуть створювати перешкоди запровадженню дорожньої концесії.

Щоб уникнути численних і великих публічних зустрічей, розробнику рекомендовано скликати цілеспрямовані групи та платформи, на яких можна визначити, проаналізувати та розглянути деталі аспектів, керуючи ними.

Зміст участі громадськості охоплює вплив проєкту, взаємодію громади, реалістичні заходи щодо пом'якшення наслідків, а також якомога більше детальної інформації та матеріалів про проєкт. Це неминуче приводить до значущішої участі зацікавлених сторін. Громада зацікавлена не лише в участі у прийнятті рішень, але й у частині зайнятості, субпідряду та розвитку стійкого потенціалу, можливостей та компетенції громади.

Часто позитивним принципом є встановлення правила, згідно 3 яким “місцеві" громади можуть скористатися перевагами проєкту та отримують преференційний режим. Це посилює підтримку громади та володіння такою програмою. Це ідеальна можливість для розвитку та участі місцевого малого та середнього бізнесу.

Важливо усвідомити, що громада ніколи не є необізнаною суттю, якою можна маніпулювати за допомогою вибіркової інформації. Громада складається із кваліфікованих та обізнаних фахівців, яких нелегко переконати в будь-яких необгрунтованих наслідках, рішеннях або запропонованих пом'якшувальних заходах. Крім того, у проєктах концесій платних доріг дуже важливо зосередитись не лише на технічній досконалості, але і розширити ऑii, передбачивши вирішення проблем громади та експлуатаційну досконалість, що сприяє покращенню обслуговування кінцевих споживачів.

Розробникам проєктів потрібно особливо усвідомлювати небезпеку низького інтересу до участі громадськості, низького рівня взаємодії та відволікання через місцеві конфлікти та політику. Запропоноване початкове профілювання громади допомогло б виявити та зрозуміти основні та внутрішні проблеми спільноти, щоб не дати змоги розв'язувати такі конфлікти під час реалізації проєкту або за допомогою проєкту.

У галузі давальницької плати необхідно врахувати, що неможливо досягти стовідсоткової участі, швидкої окупності та підтримки розвитку платної дороги. Досвід розвинених країн світу показує, що плата за дорогу, особливо у разі існування маршруту, як правило, $є$ політичним, емоційним та загалом суперечливим поняттям, що спричиняє виникнення та розвиток нових соціальних ризиків, пов'язаних із розвитком техніки та технологій. Ще одним ускладнювальним фактором $\epsilon$ те, що сторони сумніватимуться у довірі до процесу, якщо їхні прохання або протилежна позиція не будуть враховані або розглянуті. Отже, рішення про те, наскільки реально прийняти рішення під час підготовки стратегії участі громадськості та дій щодо проєкту, буде основним засобом мінімізації соціальних ризиків.

\section{Висновки}

Дорожня концесія першочергово розглядається як середньострокові, безпечні інвестиції та справедливий процес фінансування розвитку інфраструктури. Проте інвестори та позикодавці повинні усвідомлювати, що ці проєкти часто є соціально напруженими та суперечливими. Участь громадськості, зокрема громади, не можна недооцінювати, вона повинна бути всеохопною, спроможною, достовірною та добросовісною задовго до розроблення та реалізації проєктів інфраструктури платних доріг. Процес повинен передувати будь-яким остаточним безповоротним рішенням, що істотно впливають на будь-яку із зацікавлених сторін. Процес потребує стратегічного та струк- 


\section{О. І. Білик, Ю. О. Блинда, Н. М. Крохмальна}

турованого підходу із добре підготовленою структурою участі зацікавлених сторін та стратегією консультацій, що значною мірою мінімізує соціальні ризики.

На наш погляд, управління соціальним ризиком для проєктів державно-приватного партнерства в дорожній галузі є важливим елементом розвитку, який потрібно вирішувати на тому самому рівні пріоритетності, що й інженерну та фінансову складові розроблення проєктів.

\section{Перспективи подальших досліджень}

Потенційно визначеними у роботі соціальними ризиками можна скористатись для вимірювання соціальних ризиків у дорожній концесії, із застосуванням різних методів вимірювання для моніторингу й визначення будь-яких конкретних змін соціальних цінностей та соціальної стійкості під час реалізації проєктів ДПП. І навіть більше, побудову системи вимірювання соціальних ризиків можна використати для упровадження ефективних систем ризик-менеджменту для транспортних проєктів ДПП, що зменшить негативні соціальні наслідки. Саме обгрунтування та побудова системи вимірювання соціальних ризиків дорожньої концесії є подальшим напрямом тематики, яку вибрали автори.

1. Круглашов А., Бернштейн (Bernstein) Е. (2011). Політична енциклопедія. Редкол.: Ю. Левенець, Ю. Шаповал. Київ: Парламентське видавництво, С. 59-60.

2. Вікарчук О. І. (2006). Концесія у трансформаційній економіці: автореф. дис. ... канд. екон. наук: 08.01.01. Київ, 19 с.

3. Кирилова Н. В. Міжнародні стратегії розвитку державно-приватного партнерства в транспортній галузі. Available at: http://www.sworld.com.ua/index (дата звернення: 15.09.2020).

4. Маковська Ю. А. (2013). Концесійні договори, майбутне для будівництва автомобільних доріг України. Управління проектами, системний аналіз і логістика, КНТУ, Вип. 11, С. 86-94.

5. Arata M. Innovative approaches to implement road infrastructure concession through Public-Private Partnership (PPP) initiatives: a case study. Available at: www.sciencedirect.com (дата звернення: 25.09.2020).

6. Солодовнік О. О. (2017). Розвиток дорожнього господарства України у посткризовому періоді. Причорноморські економічні студіï, Вип. 23, С. 55-59. Available at: http://bses.in.ua/journals/2017/23 2017/12.pdf (дата звернення: 01.09.2020).

7. Безуглий А. О., Печончик Т. І. (2014). Економічний механізм розподілу фінансових ресурсів на потреби дорожнього господарства як складова стратегії ефективного управління автомобільними дорогами загального користування. Дороги $i$ мости, Вип. 14, С. 125-130. Available at: http://nbuv.gov.ua/ UJRN/dim_2014_14_19 (дата звернення: 25.09.2020).

8. Білик О. І. (2020). Механізми регулювання та інструменти оцінювання соціальних ризиків: монографія. Львів: Растр-7, 394 с.

9. Van Wyk J. Managing social and political risk on toll road concession projects. Available at: https://www.tollinfra.co.za/managing-social-and-political-risk-on-toll-road-concession-projects/ (дата звернення: 25.09.2020).

10. Про концесію: Закон України. Верховна Рада України. Available at: https://zakon.rada.gov.ua/ laws/show/155-IX\#Техt (дата звернення: 25.09.2020).

11. Концесія: всі “за" і “проти” державно-приватного. Available at: https://www.epravda.com.ua/ publications/2020/03/5/657701/ (дата звернення: 30.09.2020)

12. Гуренко М. (2014). Проблемні аспекти впровадження концесій в сфері будівництва та експлуатації автомобільних доріг в Україні. Вісник Київського національного університету імені Тараса Шевченка, № 1 (99). Available at: http:///Users/HP/Downloads/VKNU_Yur_2014_1_22\%20(10).pdf (дата звернення: 30.09.2020).

13. Свтушенко С. (2012). Концесійні договори: перші кроки України та досвід Свропи. Available at: http://investukraine.com/wp-content/uploads/2012/11/concession_SY.pdf (дата звернення: 25.09.2020).

14. Досвід реалізації проектів будівництва та експлуатації автомобільних доріг на умовах концесії. Дорожня галузь України, 2012, № 2. Available at: http://www.dorogy.com.ua/ukrarchive/item/2012/22012. html?field=field4 (дата звернення: 30.09.2020).

15. Про автомобільні дороги: Закон України. URL: http://zakon3.rada.gov.ua/laws/show/2862-15 (дата звернення: 30.09.2020).

16. Про Стратегію сталого розвитку “Україна-2020”: Указ Президента України. Available at: http://zakon3.rada.gov.ua/laws/show/5/2015(дата звернення: 30.09.2020).

17. Про затвердження Стратегічного плану розвитку автомобільного транспорту та дорожнього господарства на період до 2020 року: Наказ Міністерства інфраструктури України від 21 грудня 2015 року № 548. Available at: http://mtu.gov.ua/documents/358.html (дата звернення: 30.09.2020). 


\section{Особливості управління сочіальними ризиками в умовах розвитку дорожньої концесії}

1. Kruhlashov. Bernshtein E. (2011). Political encyclopedia. Yu. Levenets', Yu. Shapoval (Ed.). Applied Economics, pp. 59-60. Kyiv: Parlamentske vydavnytstvo. (in Ukrainian).

2. Vikarchuk O. I. (2006). Concession in a transformational economy. Extended abstract of candidate's thesis. Kyiv. (in Ukrainian).

3. Kirillov N. V. (2018). International strategies of public private partnerships in the transport sector. Retrieved from: http://www.sworld.com.ua/index.

4. Makovska Yu. A. (2013). Concession contracts for future construction of highways of Ukraine. Management of projects, system analysis and logistics. Kyiv: National Transport University, Vol. 11.

5. Mario Arata, Marcello Petrangeli, Francesco Longo (2016). Innovative approaches to implement road infrastructure concession through Public-Private Partnership (PPP) initiatives: a case study. Available at: www.sciencedirect.com.

6. Solodovnik O. O. (2017). Development of road economy of Ukraine in the post-crisis period [Rozvytok dorozhn'oho hospodarstva Ukrayiny u postkryzovomu periodi], Black Sea Economic Studies, Issue 23, pp. 55-59. Available at: http://bses.in.ua/journals/2017/23_2017/12.pdf (last accessed 01.09.2020).

7. Bezugly A. O., Pechonchik T. I. (2014). Ekonomichnyy mekhanizm rozpodilu finansovykh resursiv na potreby dorozhn'oho hospodarstva yak skladova stratehiyi efektyvnoho upravlinnya avtomobil'nymy dorohamy zahal'noho korystuvannya [Economic mechanism of distribution of financial resources for the needs of road economy as a component of the strategy of efficient management of public roads], Roads and bridges, Issue 14, pp. 125-130. Available at: http://nbuv.gov.ua/UJRN/dim_2014_14_19 (last accessed 25.09.2020).

8. Bilyk O. (2020). Mekhanizmy rehuliuvannia ta instrumenty otsiniuvannia sotsialnykh ryzykiv: monohrafiia [Mechanisms of regulation and tools for assessing social risks: a monograph]. Lviv: Rastr-7.

9. van Wyk J. H. (2019). Managing social and political risk on toll road concession projects. Retrieved from https://www.tollinfra.co.za/managing-social-and-political-risk-on-toll-road-concession-projects.

10. The Verkhovna Rada of Ukraine (1999). Zakon Ukrainy "Pro kontsesiiu" [The Law of Ukraine "On Concession"]. Available at: https://zakon.rada.gov.ua/laws/show/155-IX\#Text (Accessed 25 September 2020).

11. Kontsesiia: vsi "za" i "proty" derzhavno-pryvatnoho partnerstva [Concession: all the pros and cons of public-private partnership]. Ekonomichna Pravda [Economic truth]. Retrieved from: https://www.epravda.com.ua/ publications/2020/03/5/657701.

12. Hurenko M. (2014). Problematic aspects of the implementation of the concessions in the construction and maintenance of roads in Ukraine. Visnyk Kyivs'koho natsional'noho universytetu imeni Tarasa Shevchenka [Online], Vol. 1 (99). Available at: file:///C:/Users/HP/Downloads/VKNU_Yur_2014_1_22\%20(10).pd.

13. Yevtushenko C. (2012). Concession agreements first steps Ukraine and European experience. Available at: http://investukraine.com/wp-content/uploads/2012/11/concession_SY.pdf (Accessed 29 September 2020).

14. Experience of project construction and maintenance of roads in the concession. Dorozhnia haluz' Ukrainy [Online], Vol. 2. Available at: http://www.dorogy.com.ua/ukrarchive/item/2012/2-2012.html?field=field4.

15. The Verkhovna Rada of Ukraine (2005). The Law of Ukraine "On roads". Available at: http://zakon3.rada.gov.ua/laws/show/2862-15 (Accessed 17 March 2017).

16. President of Ukraine (2015). Decree of the President of Ukraine "On the Strategy for Sustainable Development" Ukraine - 2020”. Available at: http://zakon3.rada.gov.ua/laws/show/5/2015 (Accessed 17 March 2017).

17. Ministry of Infrastructure of Ukraine (2015). Order of the Ministry of Infrastructure of Ukraine "On Approval of the Strategic Plan of road transport and road sector for the period till 2020". Available at: http://mtu.gov.ua/documents/358.html (Accessed 17 March 2017).

O. Bilyk, Y. Blynda, N. Krokhmalna

Lviv Polytechnic National University,

Department of administrative and financial management

\section{PECULIARITIES OF SOCIAL RISK MANAGEMENT IN THE CONDITIONS OF ROAD CONCESSION DEVELOPMENT}

(C) Bilyk O., Blynda Y., Krokhmalna N., 2020

The road network is one of the most important branches of the economy, which performs the function of a kind of circulatory system in the complex organism of the country. It not only helps to meet the needs of the economy and the population in transportation, but together with the cities forms a "framework" of the territory, has a significant impact on the dynamism and efficiency of socio- 


\section{О. І. Білик, Ю. О. Блинда, Н. М. Крохмальна}

economic development of individual regions and the country as a whole. World experience shows that without a developed transport, automotive network can not create an efficient market economy.

Ensuring the development of the road network and improvement their transport and operational condition is a necessary condition for further socio-economic development of the state and society. Unsatisfactory condition of the road network has a negative impact on the social and economic situation of the country, international image and key indicators such as gross domestic product, development of productive forces, state budget revenues, employment, performance of road and other modes of transport and more.

The level of financing the road networks for the last 10 years makes 14-34 percent of the minimum necessary need for repair and maintenance of a network of highways defined by scientists. Due to insufficient funding, the pace of implementation of new technologies, machines, mechanisms, modern materials and structures is slow and does not meet current needs. The process of business investment in the road industry in Ukraine in modern conditions is risky due to imperfect legislation, low development of technology, which can be eliminated through the introduction of concession approaches in the development of the industry. The impact of public-private partnership on social risks is considered and ways to minimize them are suggested. Solving the problems of financial support for the repair, reconstruction and maintenance of roads requires the integration of State efforts, regional and local authorities, research and practice of their application, legal framework, as well as financial and material resources in international and Euroregional cooperation. It should be noted that the most problematic in terms of effective provision of transportation by state roads are sections of roads on international transport corridors. On the one hand, the financial and economic capabilities of the state and the region are still insufficient for their reconstruction, and on the other - the postponement of these problems has a negative impact on the national economy and contradicts international trends, prospects for the transport network.

The object of the article is the process of applying the concession to improve the financing of costs for repair, reconstruction and maintenance of roads in terms of social risks.

The subject of the article is the socio-economic relations between the subjects of the concession and the public.

The main purpose of the article is to substantiate the need for the introduction of a road concession, taking into account developed recommendations for social risk management.

In accordance with the purpose of the article, the authors set the following goals:

- definition and analysis of the conditions of public-private partnership in Ukraine;

- identification of the causes and consequences of the development of social risks in terms of road concessions based on the analysis of international experience in the application of tolls on highways;

- substantiation of the main directions of social risk management in the conditions of the road concession and formation of the corresponding conclusions.

The result of research is the authors' proposed ways to minimize social risks in terms of road concessions.

Key words: public-private partnership; road industry; social risks; road infrastructure. 